\title{
Efektivitas Pendekatan Multirepresentasi dalam Pembelajaran Berbasis Masalah untuk Meningkatkan Pemahaman Konsep Siswa SMA pada Materi Gaya dan Gerak
}

\author{
Ananda Hafizhah Putri' ${ }^{1}$, Sutrisno², Didi Teguh Chandra ${ }^{3}$ \\ 1,2,3 Program Studi Pendidikan Fisika, Universitas Pendidikan Indonesia \\ e-mail: \\ 1 anandap90@gmail.com \\ 2 tris0701@gmail.com \\ 33iditeguhchandra@upi.edu
}

\begin{abstract}
.
This study aims to obtain a comparative picture of increasing conceptual understanding between students who experience problem-based learning with a multi-representation approach and students who experience problem-based learning without a multi-representation approach. The aspects of understanding studied refer to Bloom's taxonomy, namely translation, interpretation, and extrapolation. This study used a quasi-experimental method with pre test and post test design non equivalent group design. The sample in this study were students from two class $X$ in one high school in the city of Bandung. The experimental class consisted of 28 students and the control class consisted of 25 students. The results showed that the students' understanding of the concept increased with an average n-gain in the experimental class and control class respectively, namely 0.406 with the medium category and 0.289 with the low category.
\end{abstract}

Keywords: multi representation approach, problem based learning, conceptual understanding

\begin{abstract}
ABSTRAK.
Penelitian ini bertujuan untuk mendapat gambaran perbandingan peningkatan pemahaman konsep antara siswa yang mengalami pembelajaran berbasis masalah dengan pendekatan multirepresentasi dan siswa yang mengalami pembelajaran berbasis masalah tanpa pendekatan multirepresentasi. Adapun aspek pemahaman yang diteliti merujuk pada taksonomi Bloom, yakni translasi, interpretasi, dan ekstrapolasi. Penelitian ini menggunakan metode kuasi eksperimen dengan desain pre test and post test non equivalent group design. Sampel pada penelitian ini adalah siswa dari dua kelas X di salah satu SMA di kota Bandung. Kelas eksperimen terdiri dari 28 siswa dan kelas kontrol terdiri dari 25 siswa. Hasil penelitian menunjukkan bahwa pemahaman konsep siswa meningkat dengan rata-rata n-gain pada kelas eksperimen dan kelas kontrol masing-masing yaitu sebesar 0,406 dengan kategori sedang dan 0,289 dengan kategori rendah.
\end{abstract}

Kata kunci: pendekatan multirepresentasi, pembelajaran berbasis masalah pemahaman konsep.

\section{PENDAHULUAN}

Dalam pembelajaran fisika, pemahaman konsep sangat penting untuk membangun proses berpikir siswa dalam memahami permasalahan-permasalahan sederhana hingga yang rumit (Widia, 2017). Pemahaman mengenai suatu konsep tertentu, akan memudahkan siswa dalam mempelajari konsep-konsep selanjutnya. Keutuhan konsep yang dimiliki siswa dapat membantu pembentukan kerangka berpikir ilmiah yang utuh pula. Kerangka berpikir ilmiah ini kemudian digunakan oleh siswa dalam memecahkan berbagai permasalahan sehari-hari. 
Hal ini sesuai dengan yang dinyatakan (Dahar, 2011) bahwa untuk memecahkan masalah, siswa harus mengetahui aturan-aturan yang relevan yang didasarkan pada konsep-konsep yang diperolehnya. Memahami konsep juga bertujuan agar siswa dapat mengaitkan konsep yang satu dengan yang lain, mampu menerapkan konsep dan mampu mengevaluasi tugas yang telah dikerjakan (Suryani \& Mulyani, 2019).

Pentingnya pemahaman konsep pada pembelajaran fisika tergambar pada standar isi pembelajaran Fisika di sekolah pada jenjang SMA. Pembelajaran Fisika bertujuan untuk mengembangkan kemampuan bernalar dalam berpikir analisis menggunakan konsep dan prinsip fisika untuk menjelaskan peristiwa dalam kehidupan sehari-hari dan menyelesaikan permasalahan baik secara kualitatif maupun kuantitatif (Permendikbud, 2016). Sehingga, pemahaman konsep yang benar adalah hal wajib dimiliki oleh siswa agar tujuan pembelajaran tersebut dapat terwujud.

Sayangnya, keadaan yang diharapkan pada standar isi tersebut masih belum terwujud dalam pembelajaran fisika di kelas secara umum. Melalui observasi di salah satu SMAN di kota Bandung, ditemukan bahwa pembelajaran masih berpusat pada guru dengan metode ceramah. Sebagian besar pembelajaran masih berupa transfer informasi dari guru kepada siswa dan bersifat hapalan. Pembelajaran fisika juga hanya menekankan pada soal-soal yang menggunakan rumus perhitungan. Siswa jarang melakukan praktikum atau penyelidikan dalam membahas materi fisika. Hal ini sesuai dengan yang dinyatakan oleh (Hidayah et al., 2017) bahwa pembelajaran sangat jarang dilakukan melalui kegiatan praktikum dan siswa hanya diberikan konsep tanpa ada kegiatan untuk menemukan konsep. Hal yang serupa dinyatakan oleh (Mardatila et al., 2019) yang menyatakan bahwa pada kenyataanya pembelajaran fisika terkesan monoton karena siswa hanya diajarkan kumpulan rumus semata tanpa memahami konsepnya. Dengan demikan, jelas bahwa pembelajaran fisika masih berpusat pada guru dan siswa masih belum mendapatkan pengalaman belajar yang baik, khususnya dalam memahami konsep fisika.

Dampak yang ditimbulkan dari proses pembelajaran tersebut adalah siswa bosan dan mengalami kesulitan dalam memahami konsep fisika. Kondisi ini juga disebabkan karena siswa memiliki keberagaman kemampuan yang berbeda dalam memahami konsep-konsep fisika (Simamora et al., 2016). Simamora et al., (2016) menjelaskan bahwa terdapat siswa yang sudah mampu memahami materi fisika ketika diberi penjelasan verbal saja atau gambar saja, tetapi juga terdapat sebagian siswa yang baru mampu memahami materi fisika setelah diberi penjelasan verbal dan gambar. Dengan kata lain, siswa baru memahami materi fisika ketika diberi penjelasan tambahan, seperti dibantu dengan gambar, persamaan matematika, dan lainnya.

Hal tersebut berkaitan dengan kemampuan spesifik yang lebih menonjol dibandingkan kemampuan lain pada masing-masing siswa. Terdapat siswa yang lebih menonjol dalam kemampuan verbal dibanding kemampuan visual, begitupun sebaliknya. Jika sebuah konsep dinyatakan dengan format representasi tunggal, maka kemungkinan hanya sebagian siswa yang dapat memahaminya (Simamora et al., 2016). Sebagai wujud pelaksanaan salah satu tugas guru dalam pembelajaran, yakni tugas membelajarkan, seorang guru bertugas untuk memfasilitasi dan memberikan peluang untuk belajar dengan merancang suasana yang kondusif dan mendukung proses belajar siswa (Jufri, A., 2013). Berkaitan dengan masalah yang dijelaskan sebelumnya, guru perlu merancang pembelajaran yang dapat mengaktivasi siswa serta mampu mengakomodasi keberagaman kemampuan siswa dalam memahami konsep fisika. Kondisi pembelajaran tersebut ditentukan oleh pendekatan dan model pembelajaran yang dirancang oleh guru.

Pendekatan dengan berbagai representasi (multi representasi) diprediksi dapat membantu siswa memahami konsep yang dipelajari di sekolah (Sari et al., 2015). Pendekatan multi representasi yang dimaksud berupa penggunaan berbagai bentuk representasi, seperti verbal, piktorial, diagram, grafik, matematik, dan interaktif untuk mendukung penanaman konsep dan pemecahan masalah (Van et al., 2001). Menurut (Meltzer, 2005) format representasi yang beragam dalam pembelajaran suatu konsep tertentu memberikan peluang yang cukup baik dalam 
memahami konsep dan mengkomunikasikannya, serta bagaimana mereka bekerja dengan sistem dan proses suatu konsep fisika tertentu. Suhandi \& Wibowo, (2012) juga menyatakan bahwa pendekatan multirepresentasi dapat mempertajam dan mengokohkan pemahaman konsep karena makna suatu konsep akan lebih jelas ketika disajikan dengan berbagai representasi. Oleh karena itu, multi representasi dalam pembelajaran fisika pun dapat digunakan untuk meminimalisir kesulitan dalam belajar fisika (Simamora et al., 2016)

Dua alasan utama mengapa multi representasi harus dijadikan pilihan utama dalam pembelajaran fisika (Angell et al., 2007). Pertama, pembelajaran fisika di sekolah harus merefleksikan model pembelajaran yang mengarahkan pada proses pencarian pengetahuan dan pengenalan produk pengetahuan. Kedua, pendekatan yang bermacam-macam (bervariasi) harus selalu ada dalam pembelajaran fisika. Pendapat ini diperkuat oleh Koh et al., (2007) yang mengatakan bahwa pembelajaran dengan menggunakan multi representasi dapat dianggap sebagai kunci dari pembelajaran fisika.

Adapun salah satu model pembelajaran yang dapat memfasilitasi siswa dalam mengembangkan keterampilan berpikir adalah pembelajaran berbasis masalah (PBM). Model PBM merupakan suatu model pembelajaran yang difokuskan pada pengalaman belajar yang diatur meliputi penyelidikan dan pemecahan masalah khususnya masalah yang berkaitan dengan kehidupan sehari-hari. Model PBM menyuguhkan permasalahan kontekstual untuk dipelajari sehingga dapat membangkitkan keinginan siswa untuk belajar (Mubarok, 2016). Model PBM bercirikan penggunaan masalah kehidupan nyata sebagai sesuatu yang harus dipelajari siswa untuk melatih dan meningkatkan keterampilan berfikir kritis dan memecahkan masalah, serta mendapatkan pengetahuan konsep-konsep penting (Trianto, (2017).

Penggunaan pendekatan multi representasi dalam pembelajaran berbasis masalah merupakan pembelajaran yang tepat dalam mengaktivasi siswa selama pembelajaran dan mengatasi perbedaan kemampuan siswa dalam memahami konsep. Hal ini didukung dengan berbagai penelitian yang menunjukkan bahwa pembelajaran berbasis masalah (PBM) dengan multi representasi telah banyak digunakan serta dianggap efektif dalam meningkatkan berbagai aspek kemampuan siswa. Hasil studi Agustin, (2014) menyimpulkan bahwa terdapat perbedaan yang signifikan pada hasil belajar fisika siswa saat menggunakan model PBM disertai LKS berbasis multi representasi. Arifiyanti, (2013) menyatakan model PBM dengan pendekatan multi representasi memiliki efektivitas yang tergolong tinggi dalam menurunkan kesulitan belajar dan meningkatkan kemampuan representasi siswa. Penelitian Widianingtiyas et al., (2015) menyatakan bahwa pendekatan multi representasi dapat memberikan pengaruh positif terhadap kemampuan kognitif siswa yang meliputi kognitif tingkat rendah dan kognitif tingkat tinggi. Hasil studi Sari et al., (2015) juga menyatakan pendekatan multi representasi mampu meningkatkan prestasi belajar dan konsistensi ilmiah siswa sekolah menengah atas pada materi elastisitas.

Berdasarkan latar belakang masalah dan data empiris yang telah diperoleh, maka penulis tertarik untuk melakukan penelitian dalam rangka memverifikasi efektivitas pendekatan multi representasi dalam pembelajaran berbasis masalah untuk meningkatkan pemahaman konsep siswa sma pada materi gaya dan gerak.

\section{METODOLOGI}

Metode yang digunakan pada penelitian ini adalah Quasi Experiment dengan desain penelitian pre test and post test non equivalent control group design. Pada desain penelitian ini, terdapat dua kelompok siswa, yakni sebagai kelompok eksperimen dan kelompok kontrol yang dipilih dan ditempatkan tidak secara acak. Pre test diberikan kepada kedua kelompok tersebut untuk mengetahui kemampuan awal siswa dalam hal pemahaman konsep. Kemudian, perlakuan berupa pendekatan multi representasi pada pembelajaran berbasis masalah diberikan kepada kelompok 
eksperimen. Adapun kelas kontrol hanya diberikan pembelajaran berbasis masalah saja. Setelah kedua kelompok telah menyelesaikan skenario pembelajaran yang dirancang, kedua kelompok diberikan post test untuk mengetahui kemampuan akhir siswa dalam pemahaman konsep. Desain penelitian dapat dilihat pada Tabel 1. sebagai berikut.

Tabel 1. Desain penelitian

\begin{tabular}{cccc}
\hline & Pre Test & Perlakuan & Post Test \\
\hline Kelas Eksperimen & $\mathrm{P}_{1}$ & $\mathrm{X}_{1}$ & $\mathrm{P}_{2}$ \\
Kelas Kontrol & $\mathrm{P}_{3}$ & $\mathrm{X}_{2}$ & $\mathrm{P}_{4}$ \\
\hline
\end{tabular}

Dengan :

$\mathrm{P}_{1} \quad$ : Pre Test pada Kelas Eksperimen

$\mathrm{X}_{1}$ : Pendekatan Multi Representasi pada Pembelajaran Berbasis Masalah

$\mathrm{P}_{2} \quad$ : Post Test pada Kelas Eksperimen

$\mathrm{P}_{3} \quad$ : Pre Test pada Kelas Kontrol

$\mathrm{X}_{2} \quad$ : Pembelajaran Berbasis Masalah

$\mathrm{P}_{4} \quad$ : Post Test pada Kelas Kontrol

Populasi penelitian ini adalah seluruh siswa kelas X di salah satu SMA di Kota Bandung. Adapaun sampel penelitian ini adalah dua kelas dari tingkat kelas X. Jumlah siswa pada kelas eksperimen dan kelas kontrol masing-masing berjumlah 28 dan 25 siswa.

Teknik pengumpulan data yang digunakan dalam penelitian ini adalah tes dan non tes. Instrumen yang digunakan untuk mengukur pemahaman konsep siswa adalah tes objektif berbentuk pilihan ganda yang memuat aspek translasi, interpretasi, dan ekstrapolasi. Instrumen tes ini memuat 20 butir soal dengan 5 pilihan jawaban. Soal-soal pada instrumen tes ini berkaitan dengan fenomena hukum Newton dan gaya-gaya mekanika dalam kehidupan sehari-hari. Seluruh soal pada instrumen ini hanya menuntut penggunaan pemahaman konsep siswa tanpa menggunakan perhitungan matematis. Adapun instrumen non tes yang digunakan adalah lembar observasi. Instrumen ini digunakan untuk mengetahui keterlaksanaan proses pembelajaran di dalam kelas, yakni keterlaksanaan seluruh sintak model pembelajaran berbasis masalah baik dengan maupun tanpa pendekatan multi representasi melalui observasi aktivitas yang dilaksanakan oleh guru sebagai fasilitator dalam mengaktivasi siswa dalam pembelajaran.

Instrumen tes telah divalidasi secara konstruk oleh judgement ahli sebelum diuji coba kepada siswa. Uji coba instrumen dilakukan oleh siswa kelas XII yang telah mempelajari materi gaya dan gerak di sekolah yang menjadi tempat penelitian. Uji coba instrumen menunjukkan bahwa reliabilitas instrumen sebesar 0,74 dengan kategori tinggi. Instrumen yang digunakan adalah instrumen hasil analisis validasi konstruk oleh ahli dan uji empirik kepada siswa.

Adapun analisis peningkatan pemahaman konsep siswa pada kedua kelas menggunakan gain yang dinormalisasi yang dikemukakan oleh (Hake, 1998). Rata-rata gain yang ternormalisasi $(<\mathrm{g}>)$ dinyatakan oleh persamaan sebagai berikut

$$
\langle g\rangle=\frac{\%\langle G\rangle}{\%\langle G\rangle \max }=\frac{\left(\%\left\langle S_{f}\right\rangle-\%\left\langle S_{i}\right\rangle\right)}{\left(100-\%\left\langle S_{i}\right\rangle\right)}
$$

Keterangan:

$<\mathrm{g}>\quad=$ Rata-rata gain yang ternormalisasi

$<\mathrm{S}_{\mathrm{f}}>\quad=$ Rata-rata nilai post test

$<\mathrm{S}_{\mathrm{i}}>\quad=$ Rata-rata nilai pre test

Kategori peningkatan gain yang dinormalisasi (n-gain) untuk menyatakan peningkatan kemampuan pemahaman konsep siswa pada materi gaya dan gerak dapat disajikan pada tabel. 2 . 
Tabel 2. Interpretasi n-gain

\begin{tabular}{cc}
\hline Nilai $<\mathrm{g}>$ & Interpretasi \\
\hline$(<\mathrm{g}>)>0,7$ & Tinggi \\
\hline $0,3<(<\mathrm{g}>)<0,7$ & Sedang \\
\hline$(<\mathrm{g}>)<0,3$ & Rendah \\
\hline
\end{tabular}

\section{TEMUAN DAN PEMBAHASAN}

Keterlaksanaan pendekatan multirepresentasi dalam pembelajaran berbasis masalah pada penelitian ini dapat diketahui dengan melakukan observasi aktivitas guru pada saat proses pembelajaran berlangsung yang dibantu oleh dua orang observer. Hasil observasi aktivitas guru dijelaskan pada lembar observasi keterlaksanaan pendekatan multirepresentasi yang sudah disediakan. Adapun hasil keterlaksanaan pembelajaran pada kedua kelas penelitian disajikan pada tabel 3.

Tabel 3. Keterlaksanaan pembelajaran pada kedua kelas sampel

\begin{tabular}{ccccc}
\hline \multirow{2}{*}{$\begin{array}{c}\text { Pertemuan } \\
\text { ke- }\end{array}$} & \multicolumn{2}{c}{ Kelas Eksperimen } & \multicolumn{2}{c}{ Kelas Kontrol } \\
\cline { 2 - 5 } & Persentase & Interpretasi & Persentase & Interpretasi \\
\hline 1 & $91,3 \%$ & Sangat Baik & $95,6 \%$ & Sangat Baik \\
\hline 2 & $100 \%$ & Sangat Baik & $95,1 \%$ & Sangat Baik \\
\hline
\end{tabular}

Berdasarkan tabel 3 terlihat bahwa pada pertemuan pertama, keterlaksanaan pembelajaran pada kelas kontrol lebih besar daripada kelas eksperimen. Adapun pada pertemuan kedua, keterlaksanaan pembelajaran pada kelas eksperimen lebih besar daripada kelas kontrol. Peningkatan keterlaksanaan hanya terjadi pada kelas eksperimen dan tidak terjadi pada kelas kontrol.

Adapun peningkatan pemahaman konsep siswa setelah menerima perlakuan diperoleh dari pretest dan posttest. Rekapitulasi skor rata-rata gain yang dinormalisasi tercantum pada tabel 4 sebagai berikut.

Tabel 4. Rekapitulasi skor rata-rata n-gain

\begin{tabular}{|c|c|c|c|c|c|c|}
\hline \multirow{2}{*}{ Kelas } & \multicolumn{2}{|c|}{ Pre Test } & \multicolumn{2}{|c|}{ Post Test } & \multirow{2}{*}{$\begin{array}{c}\text { Rerata } \\
\text { N-Gain }\end{array}$} & \multirow{2}{*}{ Kategori } \\
\hline & $\mathbf{X}_{\text {ideal }}$ & $\overline{\bar{X}}$ & $\mathbf{X}_{\text {ideal }}$ & $\overline{\bar{X}}$ & & \\
\hline Eksperimen & 100 & 21,15 & 100 & 53,04 & 0,406 & Sedang \\
\hline Kontrol & 100 & 19 & 100 & 42,2 & 0,289 & Rendah \\
\hline
\end{tabular}

Berdasarkan hasil analisis data dengan uji $\mathrm{N}$-gain, diperoleh bahwa pemahaman konsep siswa pada kedua kelas sampel mengalami peningkatan. Skor rata-rata n-gain pada kelas eksperimen sebesar 0,406 dengan kategori sedang dan skor rata-rata n-gain pada kelas kontrol sebesar 0,289 dengan kategori rendah. Sehingga, dapat disimpulkan bahwa peningkatan pemahaman konsep siswa pada kelas eksperimen lebih besar daripada kelas kontrol.

Peningkatan yang lebih besar pada kelas eksperimen ini dapat dijelaskan bahwa kegiatan pembelajaran khususnya dalam memahami konsep dapat menggunakan banyak bentuk, mode, atau format representasi. Hal ini sesuai dengan dengan Ainsworth, (1999) bahwa siswa dapat mempelajari konsep fisika tidak hanya dengan menggunakan satu representasi melainkan berbagai bentuk representasi. Pembelajaran ini dilakukan pada kelas eksperimen.

Penggunaan representasi dengan beragam cara dalam pembelajaran memiliki keuntungan, yaitu dapat mendorong siswa untuk berpartisipasi dan terlibat aktif dalam proses pembelajaran secara menyeluruh dan memberikan konteks yang kaya bagi siswa untuk memahami suatu konsep (Izhak \& Sherin, 2003). Hasil penelitian Suhandi \& Wibowo, (2012) juga menyatakan bahwa 
pendekatan multirepresentasi dapat mempertajam dan mengokohkan pemahaman konsep karena makna suatu konsep akan lebih jelas ketika disajikan dengan berbagai representasi.

Hasil ini sesuai dengan yang dinyatakan oleh Ainsworth, (1999) ketika menjelaskan tiga fungsi utama dari multi representasi, yaitu sebagai pelengkap dalam proses kognitif, membantu membatasi kemungkinan kesalahan interpretasi lain, dan membangun pemahaman konsep dengan lebih mendalam. Selain tiga fungsi utama di atas, multi representasi juga berfungsi untuk menggali perbedaan-perbedaan dalam suatu informasi yang dinyatakan oleh masing-masing interpretasi. Multi representasi cenderung digunakan untuk saling melengkapi dimana representasi tunggal tidak memadai untuk memuat semua informasi yang disampaikan. Hal ini sesuai dengan yang dinyatakan Sinaga et al., (2013) bahwa modus represntasi tunggal memiliki keterbatasan dalam mengungkapkan informasi yang lengkap dan konsep yang direpresentasikan tersebut. Siswa baru memahami konsep tertentu jika diberikan penjelasan tambahan, seperti bantuan gambar, persamaan matematika, dan lainnya. Hasil penelitian ini juga selaras dengan hasil penelitian Sholihah et al., (2018)yang menunjukkan perolehan n-gain dengan kategori sedang dalam meningkatkan kognitif siswa SMA.

Peningkatan pemahaman konsep siswa juga dianalisis dari peningkatan tiap aspek pemahaman. Aspek pemahaman yang diuji dalam penelitian ini terdiri dari aspek translasi, interpretasi, dan ekstrapolasi. Dilihat dari komposisi aspek pemahaman, aspek translasi adalah aspek yang termudah, kemudian interpretasi, dan yang paling sulit adalah ekstrapolasi. Gambaran peningkatan setiap aspek pemahaman untuk kelas eksperimen dapat dilihat pada tabel 5 berikut.

Tabel 5. Rekapitulasi skor tiap aspek pemahaman pada kelas eksperimen

\begin{tabular}{|c|c|c|c|c|}
\hline \multirow{2}{*}{$\begin{array}{c}\text { Aspek } \\
\text { Pemahaman }\end{array}$} & \multicolumn{2}{|c|}{ Rata-Rata Skor } & \multirow{2}{*}{$<\mathrm{g}>$} & \multirow[t]{2}{*}{ Kategori } \\
\hline & Pre Test & Post Test & & \\
\hline Translasi & 0,71 & 8,21 & 0,51 & Sedang \\
\hline Interpretasi & 16,61 & 39,11 & 0,39 & Sedang \\
\hline Ekstrapolasi & 1,67 & 5,89 & 0,28 & Sedang \\
\hline
\end{tabular}

Berdasarkan tabel 5, secara keseluruhan semua aspek pemahaman yang diteliti mengalami peningkatan dengan kategori sedang. Secara rinci, peningkatan pemahaman konsep yang terbesar terjadi pada aspek translasi, kemudian interpretasi, dan terkecil adalah ekstrapolasi.

Pada penelitian ini, aspek translasi dilatihkan kepada siswa pada proses penyajian berbagai data dan hasil percobaan siswa dalam LKPD dan tahap mengkomunikasikan. Aspek pemahaman interpretasi dilatihkan pada saat penggalian konsepsi awal, analisis fenomena-fenomena yang dilakukan pada kegiatan kelompok, serta konfirmasi dan penguatan konsep oleh guru. Adapun aspek ekstrapolasi hanya dilatihkan kepada siswa saat guru memberikan penguatan konsep saja. Ketiga aspek pemahaman ini dilatihkan kepada siswa secara multi representasi, walaupun peneliti tidak menafikan bahwa representasi verbal dan gambar merupakan representasi yang paling sering digunakan dikarenakan respons siswa secara aktif terjadi jika komunikasi saat pembelajaran menggunakan dua representasi tersebut.

Adapun untuk representasi matematis, siswa masih belum terbiasa melakukan komunikasi dan analisis secara matematis. Representasi matematis dan grafik sebagian besar diberikan oleh guru kepada siswa dan beberapa saat dilakukan siswa dengan bimbingan guru. Adapun gambaran peningkatan peningkatan tiap aspek pemahaman pada kelas kontrol dapat dilihat pada tabel 6 berikut. 
Tabel 6. Rekapitulasi skor tiap aspek pemahaman pada kelas kontrol

\begin{tabular}{ccccc}
\hline $\begin{array}{c}\text { Aspek } \\
\text { Pemahaman }\end{array}$ & \multicolumn{2}{c}{ Rata-Rata Skor } & \multirow{2}{*}{$\mathbf{P} \boldsymbol{\rangle}$} & Kategori \\
\cline { 2 - 3 } Translasi & 2,4 & 5,6 & 0,19 & Rendah \\
\hline Interpretasi & 14,2 & 33,6 & 0,32 & Sedang \\
\hline Ekstrapolasi & 1 & 2,2 & 0,08 & Rendah \\
\hline
\end{tabular}

Berdasarkan tabel 6, secara keseluruhan semua aspek pemahaman yang diteliti mengalami peningkatan. Secara rinci, diperoleh bahwa peningkatan pemahaman konsep yang terbesar terjadi pada aspek interpretasi, kemudian translasi, dan terkecil adalah ekstrapolasi.

Pada penelitian ini, aspek pemahaman translasi dilatihkan pada saat konfirmasi dan mengkomunikasikan hasil penyelidikan. Pada aspek translasi, pemahaman konsep siswa mengalami kenaikan dengan gain ternormalisasi sebesar 0,19 pada kategori rendah. Aspek pemahaman interpretasi dilatihkan pada saat penggalian konsepsi awal, pembuatan prediksi, dan analisis fenomena-fenomena yang dilakukan pada kegiatan kelompok. Aspek pemahaman interpretasi mengalami peningkatan dengan gain ternormalisasi 0,32 pada kategori sedang. Sedangkan aspek pemahaman ekstrapolasi diberikan pada saat penguatan konsep oleh guru saja. Hal ini dikarenakan siswa masih cukup kesulitan denganmenafsirkan (interpretasi) data, sehingga peneliti cukup terfokuskan pada tahap konfirmasi konsep/fenomena yang telah dipelajari. Aspek pemahaman ekstrapolasi mengalami peningkatan dengan gain ternormalisasi 0,08 pada kategori rendah. Ketiga aspek pemahaman ini dilatihkan kepada siswa tidak secara representasi. Secara keseluruhan, komunikasi pada pembelajaran ini hanya berupa analisis verbal terhadap permasalahan/penyelidikan kelompok dan penjabaran verbal berbantuan gambar dalam penguatan konsep yang disampaikan oleh peneliti.

Berdasarkan pemaparan di atas, terlihat bahwa kedua kelas mengalami peningkatan untuk semua aspek pemahaman yang diteliti. Tetapi, jika dikaji lebih dalam, kedua kelas sampel mengalami besar peningkatan yang berbeda. Hal ini terlihat dari nilai gain yang dinormalisasi pada tiap aspek yang diteliti. Perbedaan tersebut dapat dilihat pada gambar 1.

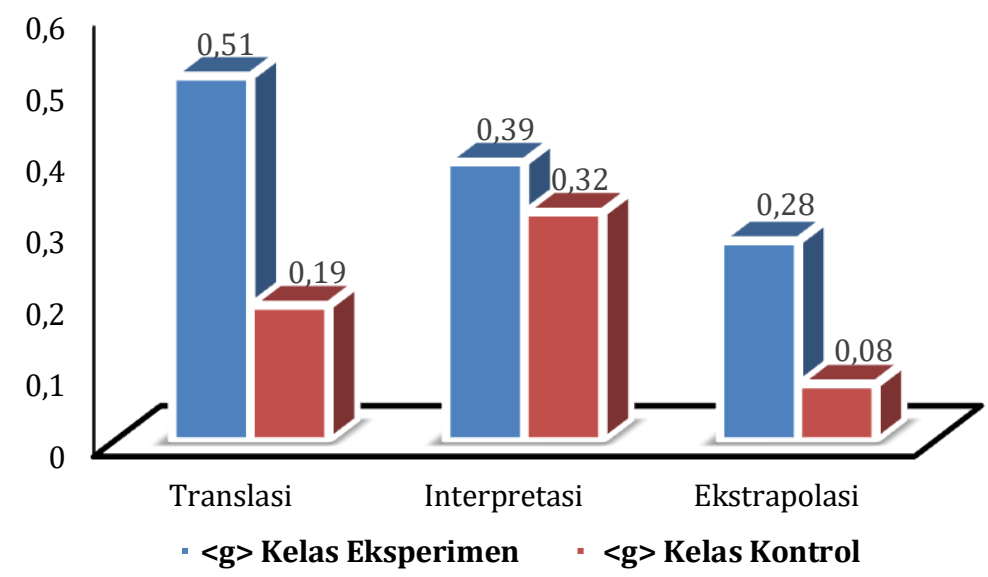

Gambar 1. Diagram peningkatan tiap aspek pemahaman

Efektivitas pendekatan multi representasi dalam pembelajaran berbasis masalah dalam meningkatkan pemahaman konsep dapat dikaji dengan menghitung n-gain pada tiap aspek pemahaman konsep. Adanya perbedaan peningkatan pemahaman konsep pada setiap aspek pemahaman antara kelas eksperimen dan kelas kontrol disebabkan oleh perbedaan pendekatan pembelajaran yang digunakan. 
Pada kelas eksperimen, pembelajaran menggunakan pendekatan multirepresentasi yang menyajikan konsep atau materi fisika dengan berbagai bentuk representasi seperti gambar, grafik, dan matematis, dan diagram gaya bebas. Pendekatan ini terlihat pada penyusunan LKPD dan slide PPT materi yang menjadi acuan utama peneliti dalam menyampaikan materi dan konsep fisika. Hal ini membuat siswa lebih terlatih dalam menafsirkan data (interpretasi) dan meramalkan kecenderungan data (ekstrapolasi). Selain itu, melalui pendekatan multi representasi, peneliti lebih mudah melakukan verifikasi pemahaman konsep siswa dengan menanyakan suatu konsep dengan format yang berbeda. Berikut adalah contoh aktivitas siswa pada kelas eksperimen.

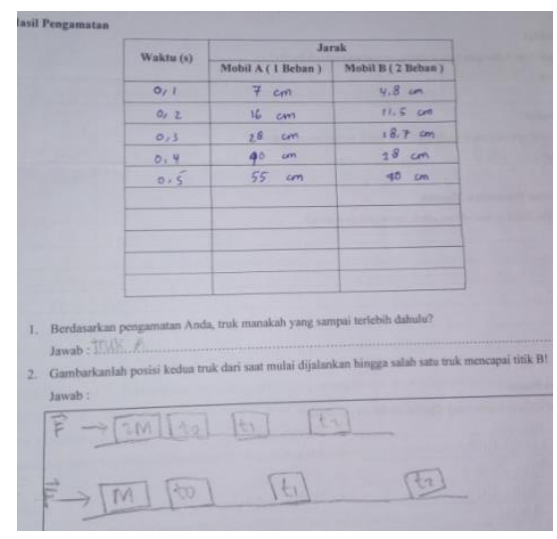

\section{Gambar 2. Jawaban LKPD siswa pada kelas eksperimen}

Pada gambar di atas, siswa mencoba melakukan penerjemahan (translasi) data dari bentuk tabel ke dalam bentuk gambar. Penulis masih menemukan banyak kekurangan pada jawaban siswa. Kekurangan ini kemudian diperbaiki oleh peneliti pada tahap menanggapi hasil diskusi oleh guru. Pada jawaban siswa tersebut, siswa sudah berusaha menggambarkan keadaan gaya yang konstan dengan menggambarkan anak panah yang sama panjang pada dua benda yang berbeda massanya. Posisi benda pada $\mathrm{t}_{0}$ harusnya dalam keadaan diam (gambar kotak paling kiri) dan pada detik berikutnya, kotak harus digambarkan dengan garis putus-putus sehingga terlihat bahwa benda dalam bergerak (mengalami perubahan posisi tiap satuan waktu). Agar proses penerjemahan data benar terjadi, maka posisi balok pada gambar harus berbasis pada tabel data percobaan. Adapun jawaban siswa di atas dapat menimbulkan persepsi lain, yakni terdapat banyak benda di waktu-waktu tertentu. Selain itu, gambar yang dibuat oleh siswa juga tidak berbasis data. Perbaikan mengenai kekurangan tersebut, disampaikan oleh peneliti pada tahap menanggapi hasil diskusi.

Adapun pada kelas kontol, pembelajaran berbasis masalah didomininasi oleh penggunaan komunikasi verbal saja, baik pada LKPD maupun slide PPT materi yang dibuat oleh peneliti. Hal ini membuat siswa kurang terlatih dalam menerjemahkan, menafsirkan, dan memprediksi suatu permasalahan yang membutuhkan satu atau beberapa konsep tertentu.

\section{SIMPULAN}

Berdasarkan hasil penelitian dapat disimpulkan bahwa pemahaman konsep siswa meningkat setelah menggunakan pembelajaran berbasis masalah baik dengan pendekatan multirepresentasi ataupun tanpa pendekatan multi representasi pada materi gaya dan gerak. Hal ini ditunjukkan dengan hasil analisis n-gain pada kedua kelas sampel, yakni 0,406 dengan kategori sedang pada kelas eksperimen dan 0,289 dengan kategori rendah pada kelas kontrol. Perbedaan kategori peningkatan pemahaman konsep pada kedua kelas sampel menunjukkan bahwa pendekatan multi representasi lebih efektif untuk meningkatkan pemahaman konsep siswa dalam pembelajaran berbasis masalah pada materi gaya dan gerak. 
Adapun berdasarkan hasil observasi keterlaksanaan pembelajaran, peneliti memberikan saran untuk mengembangkan strategi yang lebih mengakomodir seluruh siswa agar berperan aktif selama pembelajaran, terutama pada tahapan penyelidikan kelompok, diskusi dalam pengerjaan LKPD dan mengkomunikasikan hasil penyelidikan. Selain itu, dibutuhkan juga pengembangan strategi yang dapat memastikan multi representasi yang dilakukan oleh siswa dapat menjelaskan konsep yang benar dan tidak memunculkan miskonsepsi.

\section{PENGHARGAAN}

Terimakasih kepada bapak Didin Aminuddin, S.Pd. Gr., selaku guru mata pelajaran Fisika, yang telah memberikan kemudahan kepada peneliti untuk melakukan penelitian pada kelas yang beliau ajar serta arahan dalam menghadapi siswa agar dapat meminimalisir kekurangan pada penelitian ini.

\section{REFERENSI}

Agustin, D. . (2014). Penerapan Model Pembelajaran Berbasis Masalah (PBM) disertai LKS Berbasis Multirepresentasi pada Pembelajaran IPA-Fisika di SMP (Skripsi). Universitas Jember.

Ainsworth, S. (1999). The functions of multiple representations. Computers \& education, 33(2-3), 131-152.

Angell, C., O. Guttersrud, \& E., \& Henriksen. (2007). Multiple representations as a framework for a modelling approach to physics education. University of Oslo, School of Education.

Arifiyanti, F. (2013). Penggunaan Model Problem Based Learning dengan Multirepresentasi pada Usaha dan Energi di SMA (Skripsi). Universitas Tanjungpura.

Dahar, R. W. (2011). Teori-Teori Belajar \& Pembelajaran. Bandung: Erlangga.

Hake, R. R. (1998). Interactive-Engagement Versus Traditional Methods: A Six-ThousandStudent Survey of Mechanics Test Data for Introductory Physics Courses. American Journal of Physics, 66(1), 64-74.

Hidayah, N., Arifuddin, M., \& Mahardika, A. (2017). Meningkatkan Keterampilan Proses Sains pada Pembelajaran Fisika Menggunakan Metode Percobaan. Berkala Ilmiah Pendidikan Fisika, 5(2), 198-212.

Izsák, A., \& Sherin, M. G. (2003). Exploring The Use of New Representations as a Resource for Teacher Learning. School Science and Mathematics, 103(1), 18-27.

Jufri, A., W. (2013). Belajar dan Pembelajaran Sains. Bandung: Pustaka Reka Cipta.

Kohl, B. P., Rosengrant, D., \& Finkelstein, N. D. (2007). Strongly and Weakly Directed Approaches to Teaching Multiple Representation Use in Physics. Physics Education Research, 3(1), 1-10.

Mardatila, A., Novia, H., \& Sinaga, P. (2019). Penerapan Pembelajaran Fisika Menggunakan Multi Representasi untuk Meningkatkan Kemampuan Kognitif dan Pemecahan Masalah Siswa SMA pada Pokok Bahasan Gerak Parabola. Omega: Jurnal Fisika dan Pendidikan Fisika, 5(2), 33-39.

Meltzer, D. E. (2005). Relation Between Students' Problem-Solving Performance and Representational Format. American Journal of Physics., 73(5), 463-478.

Mubarok, O. S. (2016). Pengaruh Model Pembelajaran Berbasis Masalah dengan Pendekatan Saintifik terhadap Kemampuan Argumentasi Ilmiah Siswa SMA pada Materi Pengukuran (Skripsi). Universitas Pendidikan Indonesia. 
Permendikbud. (2016). Permendikbud Nomor 21 Tentang Standar Isi Pendidikan Dasar dan Menengah.

Sari, A. P., Feranie, S., \& Karim, S. (2015). Penerapan Pembelajaran Berbasis Masalah dengan Pendekatan Multireprentasi terhadap Peningkatan Prestasi Belajar dan Konsistensi Ilmiah pada Materi Elastisitas. Jurnal Penelitian \& Pengembangan Pendidikan Fisika, 1(2), 45-50.

Sholihah, A., Sinaga, P., \& A. (2018). Multi Representasi Momentum dan Impuls untuk Meningkatkan Kognitif dan Kemampuan Pemecahan Masalah iswa SMA. Prosiding Seminar Nasional Quantum, 338-344.

Simamora, M, R., Sinaga, P., \& Jauhari, A. (2016). Pembelajaran Fisika Menggunakan Multi Representasi untuk Meningkatkan Kemampuan Kognitif dan Kemampuan Pemecahan Masalah Siswa SMP pada Pokok Bahasan Getaran dan Gelombang. Prosiding Simposium Nasional Inovasi dan Pembelajaran Sains (SNIPS).

Sinaga, P., Suhandi, A., \& L. (2013). Meningkatkan Kemampuan Multi Representasi dan Translasi antar Modus Representasi Konsep Listrik Magnet pada Program Pre Service Guru Fisika. Prosiding Simposium Nasional Inovasi dan Pembelajaran Sains (SNIPS).

Suhandi, A., \& Wibowo, F., C. (2012). Pendekatan Multirepresentasi dalam Pembelajaran UsahaEnergi dan Dampak terhadap Pemahaman Konsep Mahasiswa. Jurnal Pendidikan Fisika Indonesia, 8(1), 1-7.

Suryani, I., \& Mulyani, R. (2019). Penerapan Model Pembelajaran Heuristic Vee Terhadap Peningkatan Pemahaman Konsep Siswa Pada Materi Fluida Statis. Journal of Natural Science and Integration., 2(2), 173-180.

Trianto. (2017). Mendesain Model Pembelajaran Inovatif, Progresif, dan Kontekstual. Jakarta: Kencana.

Van Heuvelen, A., \& Xueli, Z. (2001). Multiple Representation of Work-Energy Processes. American Journal of Physics, 69(2), 184-194.

Widia, Y. (2017). Pembelajaran Fisika Menggunakan Multiple External Representations (MERS) untuk Meningkatkan Pemahaman Konsep dan Konsistensi Ilmiah Siswa SMA Pada Pokok Babasan Gerak Lurus (Skripsi). Universitas Pendidikan Indonesia.

Widianingtiyas, L, D. (2015). Pengaruh Pendekatan Multi Representasi dalam Pembelajaran Fisika Terhadap Kemampuan Kognitif Siswa SMA. Jurnal Penelitian \& Pengembangan Pendidikan Fisika, 1(1), 31-38. 